\title{
Parameters Estimation at Ungauged Catchments Using Rainfall-Runoff Model, Upper Tekeze Basin, Ethiopia
}

\author{
Amare Tadesse Muche \\ Faculty of Water Resources and Irrigation Engineering, Arbaminch Water Technology Institute, Arbaminch, Ethiopia \\ Email address: \\ tadesseame@gmail.com

\section{To cite this article:} \\ Amare Tadesse Muche. Parameters Estimation at Ungauged Catchments Using Rainfall-Runoff Model, Upper Tekeze Basin, Ethiopia. \\ Engineering Science. Vol. 6, No. 3, 2021, pp. 45-56. doi: 10.11648/j.es.20210603.13
}

Received: May 8, 2021; Accepted: August 10, 2021; Published: August 18, 2021

\begin{abstract}
This study was conducted for parametres estimation and stream flow prediction at ungauged catchments on the case of Upper Tekeze basin, Ethiopia by using Rainfall-runoff model. In the basin, most of the catchments were ungauged. The basin has $9199 \mathrm{~km}^{2}$ and $3638 \mathrm{~km}^{2}$ gauged and ungauged catchments respectively. Rainfall and stream flow data were analyzed in the period of 1992-2006 and 1992-20006, respectively. Parameters calibrated for gauged catchments were extrapolated to ungauged catchments on the base of similar physical catchment characteristics using regionalization techniques. Regionalization methods such as multiple linear regression, spatial proximity, sub basin mean and area ratio were applied to transfer model parameters values from gauged to ungauged catchments. For this study seven gauged catchments were satisfied objective functions in the calibrated and validation period, for example in Gheba catchment Nash-Sutcliffe model efficiency coefficient (NSE), relative volume error (RVE) and coefficient of determination $\left(\mathrm{R}^{2}\right)$ were, $0.81,-4.25,0.77$ and $0.71,5.5,0.74$ respectively. Stream flow simulation at ungauged catchments by using spatial proximity and sub basin mean method were contributing high runoff volume compare to other methods. The result for this study shows that the Key model parameters like runoff coefficient (Beta), recession coefficient of upper reservoir zone (Khq), Limit for evapotranspiration (Lp), field capacity $(\mathrm{Fc})$, percolation (Perc) as defaulting value when applying HBV-96 model to the future regionalization studies. Model parameters were calibrated manually by try and error rules, however it was tidies therefore more creative automatic model calibration techniques could be useful for upcoming studies. Thus, Current and future water resources development endeavors may use apply such discharge data for planning and design purposes.
\end{abstract}

Keywords: HBV-96 Model, Parameter Estimation, Regionalization, Ungauged Catchment, Upper Tekeze Basin

\section{Introduction}

Hydrological data are energetic for assessment of water resources problems, however most of Ethiopian river basins are ungauged. Poorly recorded and not well managed hydrological data that causes failurty of most water and civil structures. This scarce hydrological data results uncertainty both in design and management of water resources system [11]. The situation in Upper Tekeze basin is more challenging there is no evenly distributed hydrometric stations and large areas have a lack of gauged stations and only a few years of data are available and recorded. Therefor it is better to understand the overall hydrological regime of the basin.

Models are used as utility of water resources development, in assessing and analyzing the available water resources, in studying the impacts of human interference in an area such as land use land cover change, deforestation and other hydraulics structures such as dams and reservoirs [10]. Understanding the basic relationships between rainfall-runoff, soil moisture, ground water level and land use land cover is vital for an effective and sustainable water resources planning and management activities with the support of models [14].

Estimation of flow at ungauged catchments are often based on transferring information from gauged to ungauged sites by using area ratio, spatial proximity, sub-basin mean and regional model methods [18]. The most common approaches used for estimating flow at ungauged catchments is the use of conceptual rainfall-runoff models whose limits can be regionalized, with comparable catchment characteristics shows similar hydrological behaviors [14].

This regionalization method allows using the relationship 
between model parameters and physical catchment characteristics of upper Tekeze basin by using HBV-96 model. The aim of this study was to simulate stream flow at ungauged catchments using rainfall-runoff models to solve water resource problems in the basin. Using few input variables such as rainfall, evapotranspiration, temperature, elevation zone, soil and land use land cover data to simulate stream flow at ungauged catchments in upper Tekeze basin.

In general stream flow simulation at ungauged catchments were important to asses surface and sub-surface water resource potential. Thus, simulated flows at ungauged catchments used for future water resources planning and design system in the basin yet.

\section{Materials and Methods}

\subsection{Study Area Description}

Tekeze river basin is located in the northwest of Ethiopia between $11^{\circ} 40^{\prime}$ and $15^{\circ} 12^{\prime} \mathrm{N}$ latitude, and $36^{\circ} 30^{\prime}$ and $39^{\circ} 50^{\prime} \mathrm{E}$ longitude. It is bordered by Mereb river basin and by Eritrea in the north, the Atbara river plains in Sudan in the west, Abbay river basin in the south and Danakil basin in the east. The basin has a total area of about $86,510 \mathrm{~km}^{2}$. But the study area has total area of $45580 \mathrm{~km}^{2}$. Elevation of the basin 500 low land and 3000 highland and $4620 \mathrm{~m}$ above mean sea level on Mount Rash Dashen. Annual rainfall is $600 \mathrm{~mm}$ in the lowlands and $1,300 \mathrm{~mm}$ highland. Minimum and maximum Temperature is $321^{\circ} \mathrm{C}$ and $19-43^{\circ} \mathrm{C}$. In upper Tekeze basin catchment characterized by seven major soil groups those are chromic Vertisols, Eutric Leptosols, Eutric Cambisols, Eutric Regosols, Eutric Fluvisol and Eutric Nitosol. Major land use land cover data of the catchment was characterized by annual crop, bar soil, closed shrub, moderate forest, perennial crop, wood land, Open grass, closed grass, sparse forest, open shrub and water body. The study area has $45,580 \mathrm{~km}^{2}$ among these the basin has $9199 \mathrm{~km}^{2}$ and $3638 \mathrm{~km}^{2}$ gauged and ungauged catchments.

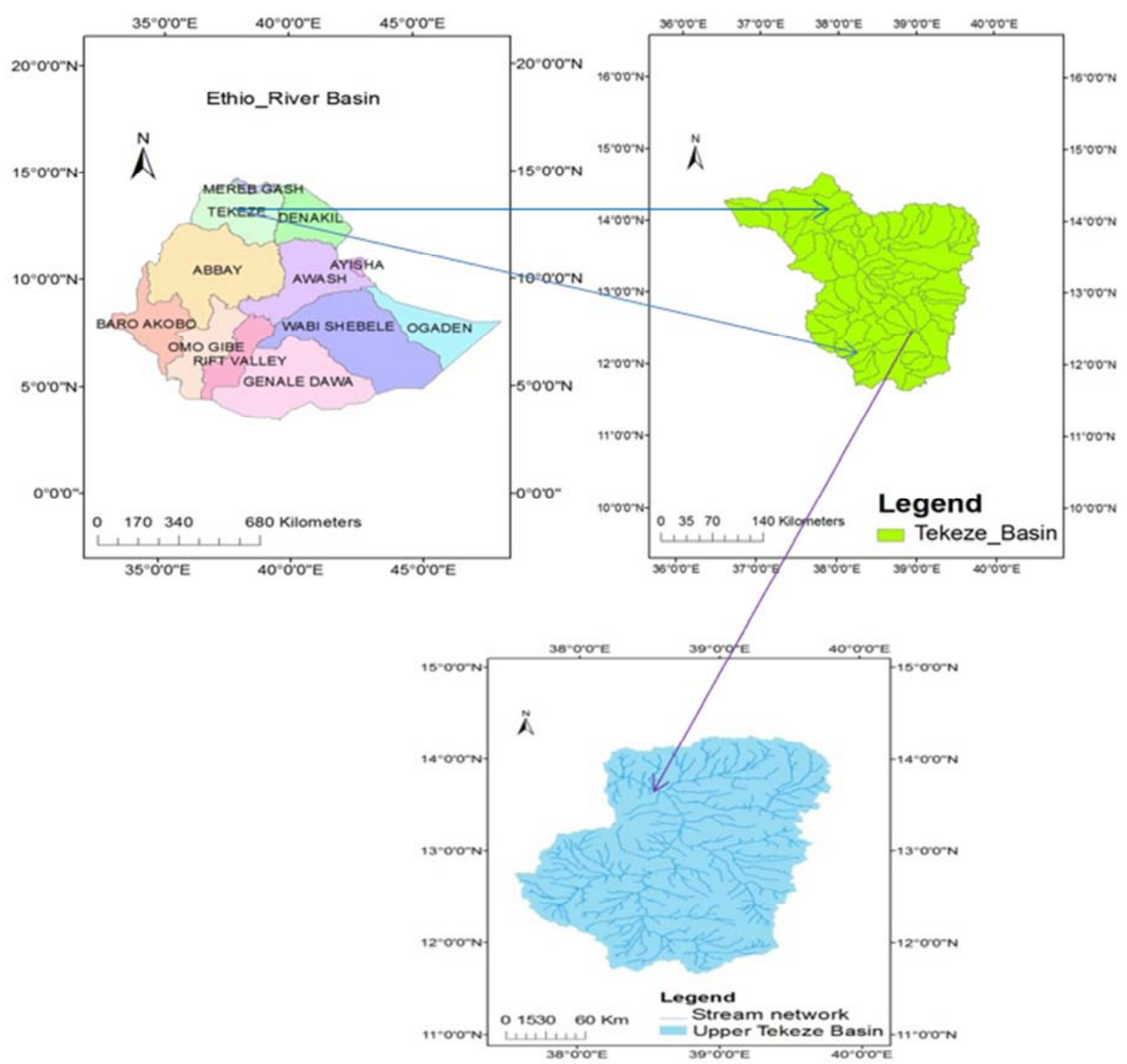

Figure 1. Location of the study area. 


\subsection{Data Collection}

Depending on the availability and suitability of hydrological stations, stream flow from1992-2006 years data collected from Ministry of Water, Irrigation and Electricity (MoWIE) under Hydrology department for model calibration and validation. Daily rainfall from16 years (1992-2006) data were collected from National Meteorological Agency (NMSA) and 30*30 DEM, LULC and soil data are used for identification of physical catchment characteristics both gauged and ungauged catchments from Ministry of Water, Irrigation and Electricity (MoWIE) under GIS department.

\subsection{Analysis of Hydro-Meteorological Data}

After selection of representative sites and collecting the required data for the model, missing rainfall and flow data were field using station average, normal ratio and regression equations respectively. The data continuity and consistency were checked, therefore the bar graphs annual rainfall during 1992-2006 periods along with the 16-year mean rainfall were plotted to explore the annual rainfall pattern over the study area and then using double mass curve analysis to check homogeneity and consistency of rainfall as well as adjustment of inconsistent data.

Evapotranspiration was calculated by using Penman-Monteith and Hargreaves methods depending on the availability of data. However, Penman-Monteith method is recommended as the lone method for determining reference evapotranspiration (ETo) when the standard meteorological variables including air temperature, relative humidity and sunshine hours data are available [15]. Since some of meteorological stations had maximum and minimum temperature. Therefore, it was recommended to use Hargreaves method.

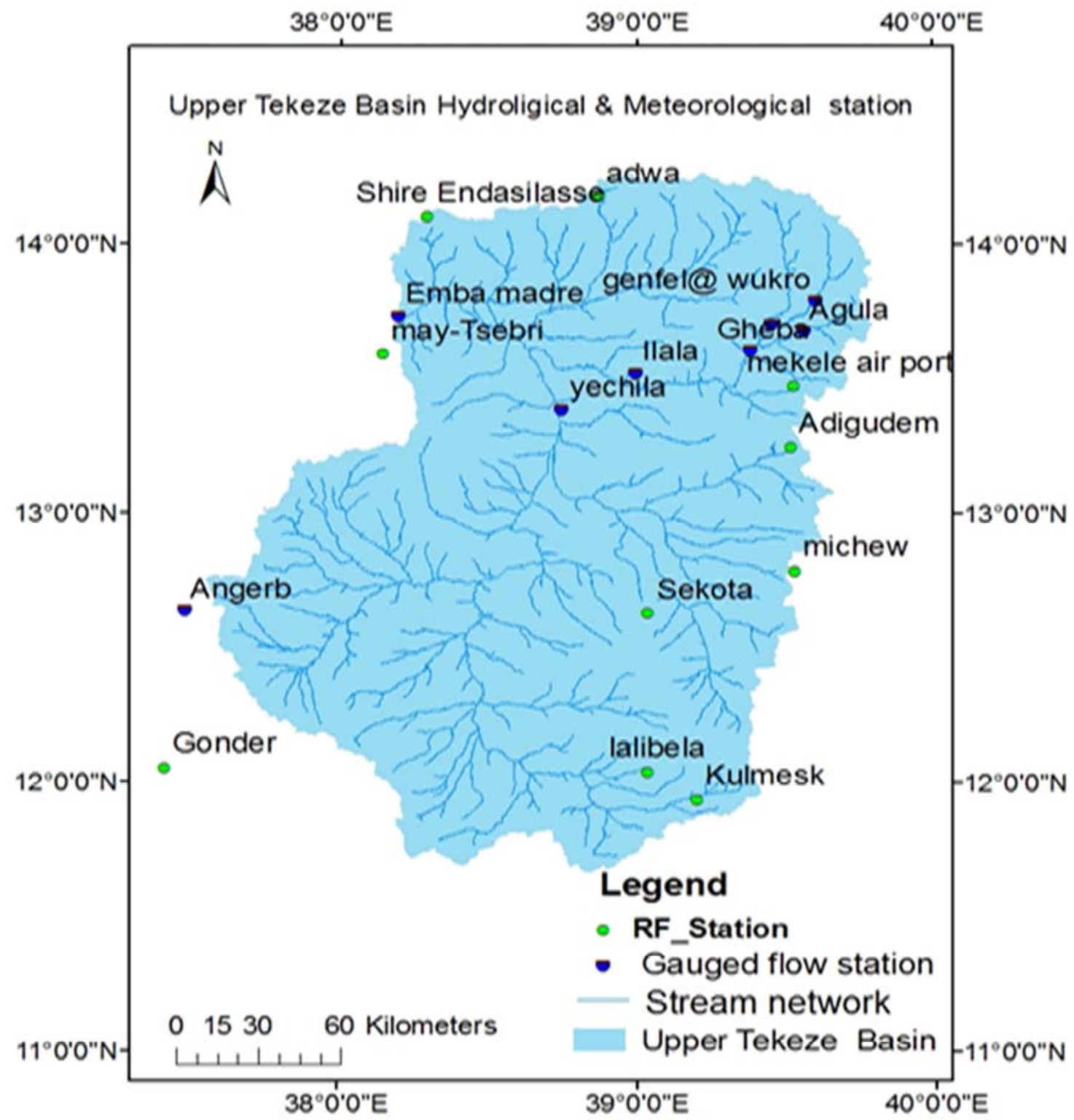

Figure 2. Location of Hydro-Meteorological stations. 


\subsubsection{Catchment Delineation and Selection of Representative Catchments}

There are 39 gauged stations in the catchment however, seven gauged catchments were selected based on the availability of daily time series river flow data.

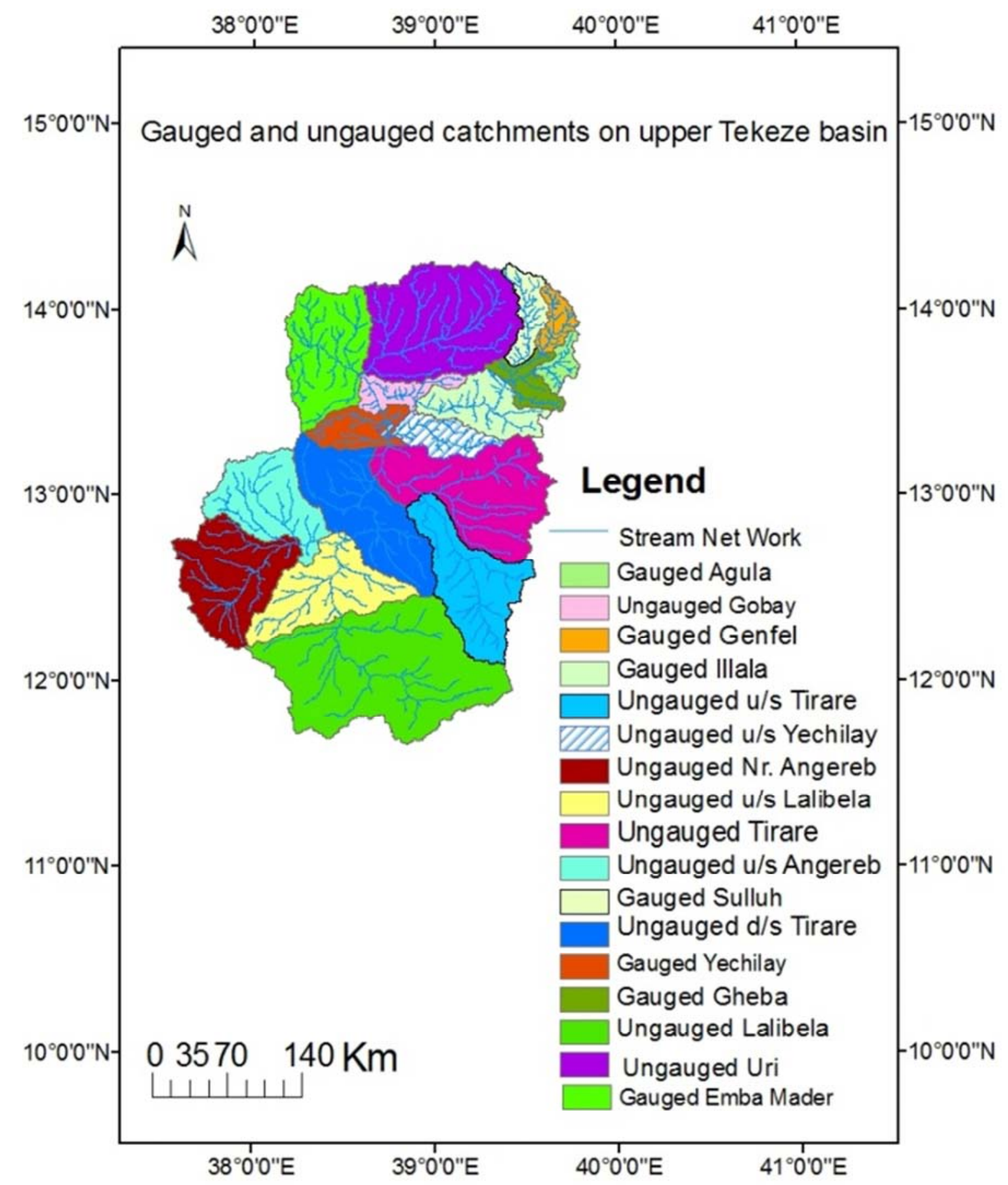

Figure 3. Gauged and ungauged major tributaries of upper Tekeze sub-basin.

\subsubsection{Selection of Representative Physical Catchment Characteristics}

Runoff generation is governed by physical catchment characteristics both gauged and ungauged catchments. In upper Tekeze basin a SRTM DEM 30*30m resolution has been used to delineate catchments of the study area by using Arc GIS and Soil and Water assessment Tool (SWAT) with
GIS interface software. Selected catchment characteristics were used to develop methods to estimate stream flow characteristics for ungauged catchments. Physical catchment characteristics both gauged and ungauged catchments were identified that are overbearing for regionalization process such as geography, physiographic, soil type, land use and land cover and geology data [8]. 


\subsubsection{Model Sensitivity Analysis}

Sensitivity analysis was performed for each calibration event by varying each of the above parameters by plus or minus $20 \%, 40 \%, 60 \%, 80 \%$ etc., in separate simulations, and then calculating the percentage change in output parameters at a time [1]. Those model parameters having steep slope are considered as most sensitive whereas those having moderate to gentle slopes are considered as less sensitive.

\subsubsection{Model Calibration and Validation}

The applicability of the model should be evaluated through the process of sensitivity analysis, calibration and validation for further analysis of the result [17]. Calibration is carried out by trial-and-error procedure whereas model parameters are manually or automatic calibration. However, in this study manual calibration method was used a period 1993-2002 for calibration and 2003-2006 for validation with one year warm up period from 1992-1993. By changing one model parameter at a time until observed flow match with simulated stream flow.

\subsubsection{Model Performance}

For this study the model performance was evaluated by Nash-Sutcliffe model efficiency coefficient (NSE), coefficient of determination $\left(\mathrm{R}^{2}\right)$ and relative volume error (RVE) for HBV -96 model for the calibration and validation period.

\subsubsection{Checking the Model Performance}

Simulate stream flow at ungauged catchments are important to check the model performance. For this study take three gauged catchments such as Emba Mader, Illala and Gheba let ungauged and transfer model parameters from four gauged catchments like Yechilay, Sulluh, Genfel and Agula using regionalization technique and simulate flow at ungauged catchments. Finally compare simulated and observed flow; if the simulated and observed flows are highly correlated to each other the model has best performance otherwise the reverse is true.

\subsubsection{Regionalization}

Regionalization is the process of transferring information from comparable catchments to the catchments of interest [3]. To generate flow at ungauged catchments it is vital to use regionalization to transfer information from gauged to ungauged catchments. Stream flow simulation needs a model parameters optimization for gauged catchments by fitting the observed and simulated stream flow [6]. For this study four regionalization methods are applied those are:

a) Regional model: Catchments for which flow time series are to be estimated may not have comparable gauged catchments [2]. Therefore, the methods of regionalization using similarity of catchment characteristics of regional model were applied to estimate the flow of ungauged catchments [12]. Each model parameters estimated by regional model was resulting using equation.

b) Spatial proximity: choice of catchments information is to be transferred gauged to ungauged site is usually based on similarity of catchment characteristics measure. This method is based on the underlying principle that catchments that are close to each other will likely have a similar runoff regime since climate and catchment conditions will often only vary marginally in space [9]. Catchments are highly homogeneous with respect to topographic and climatic properties that means land cover, soil, geology and physiographic and climate physical catchment characteristics [16].

c) Area ratio: Optimized model parameters of gauged catchments are directly transferred to ungauged catchments of equivalent area based on the assumption that catchment area is the dominant factor for controlling the volume of water that can be generated from the rainfall. If the area ratio between gauged and ungauged catchments is greater than $50 \%$, the model parameters of gauged catchments are not transferred to ungauged catchments [5].

d) Sub-basin mean: sub-basin mean represents the arithmetic mean of calibrated model parameter sets of gauged catchments that fulfill the objective functions [7].

\subsubsection{Establishing the Regional Model}

In order to set up a regional model to predict the model parameters in ungagged catchments, a statistically significant relationship established between Physical catchment characteristics and calibrated model parameters by using excel in data analysis. After determining the model parameters through model calibration and selection of physical catchment characteristics, a method for establishing the relationship is applied [13].

\subsubsection{Estimation of Model Parameters and Stream Flow Prediction at Ungauged Catchments}

After determining simple linear relationships between model parameters and physical catchment character tics, optimizing by multiple regressions analysis for several physical catchment character tics. The main objective is that select relationships that are acceptable and statistically significant.

\subsection{Spatial Temporal Data}

\subsubsection{Topographic Map}

SRTM $30 \times 30$ DEM was downloaded from earth explorer. The upper Tekeze catchments was extracted from Ethiopian DEM.

\subsubsection{Land use Landcover Map}

From ERDAS 2008 LULC map for the study is the generated classification are as follows Shrub land, Cultivation, bare land, woodland, waterbody, plantation, natural forest and grass land etc. 


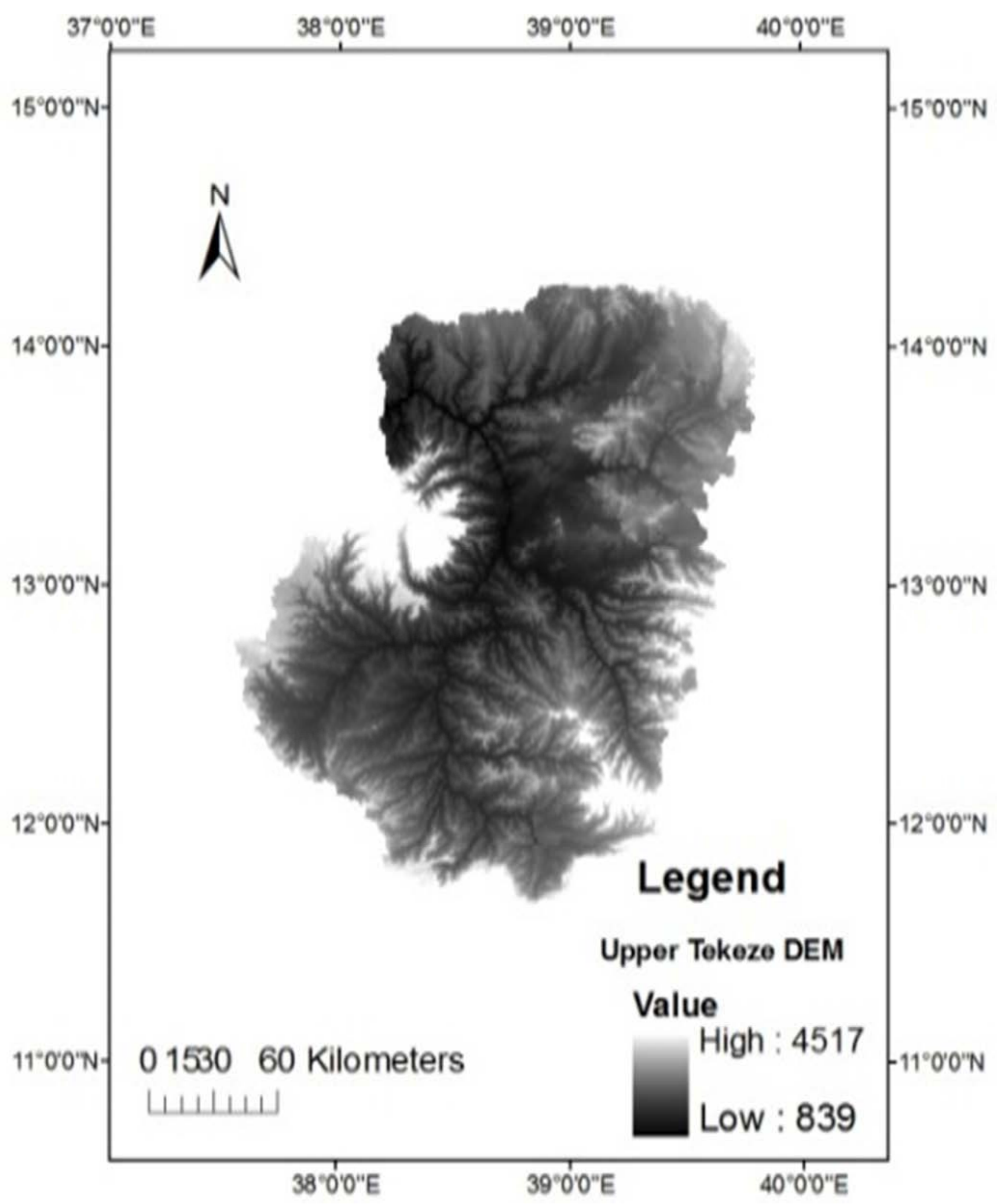

Figure 4. SRTM $30 * 30$ DEM of upper Tekeze basin. 


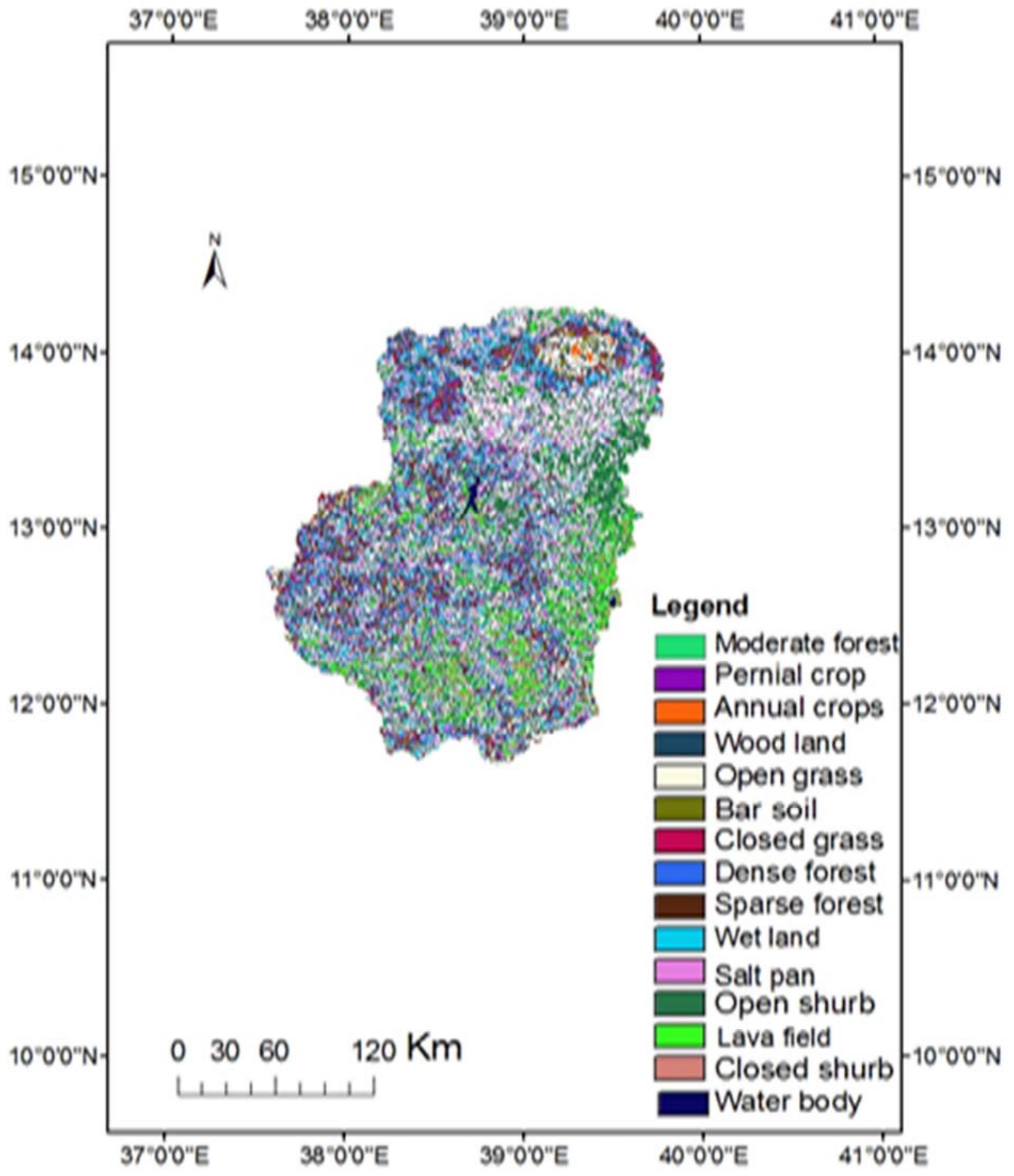

Figure 5. Land use land cove map of the study area.

\section{Results and Discussions}

\subsection{Model Development HBV-96}

\subsubsection{Sensitivity Analysis}

For this research work sensitivity analysis, like runoff coefficient (Beta), recession coefficient of upper reservoir zone (Khq), percolation (Perc), Limit for evapotranspiration (Lp) and field capacity (Fc) were more sensitive model parametres, whereas recession coefficient for lower reservoir
$\left(\mathrm{K}_{4}\right)$, capillary rise coefficient (cflux) and response routine (Alfa) are relatively less sensitive for upper Tekeze sub-basin. For this research work model parameters such as response routine (alfa), capillary rise coefficient (cflux) and recession coefficient for lower reservoir $\left(\mathrm{K}_{4}\right)$ do not show significant effect on the model performance, however for other researchers' such as Bishaw, (2012), Birhane, (2013) and Tesfaye, (2011) analysis model parametres like lower reservoir $\left(\mathrm{K}_{4}\right)$ and response routine (Alfa) shows significant effect [4]. For this study sensitivity analysis of Emba Madre sub basin as shown below. 

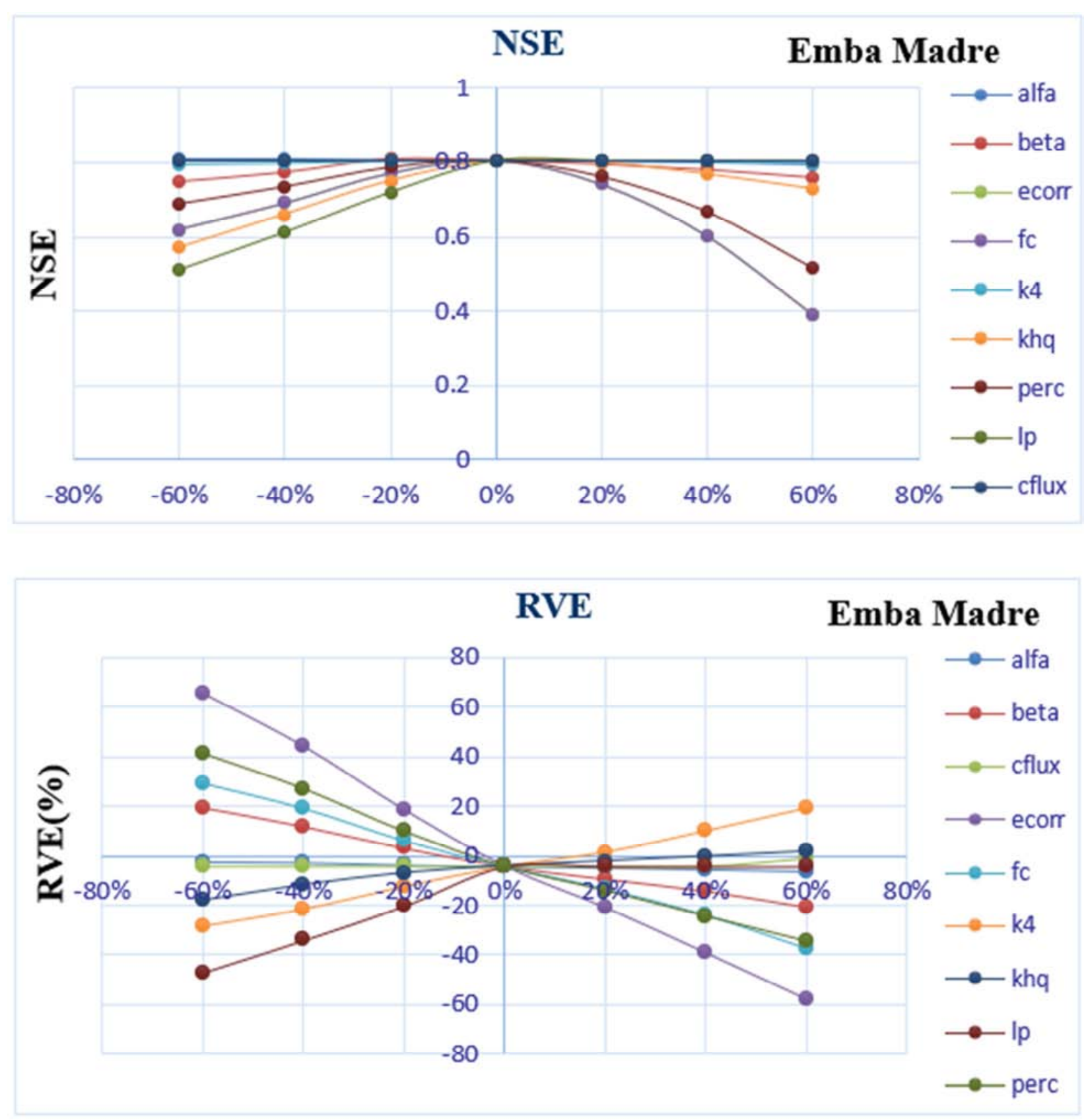

Figure 6. Sensitivity analysis of Emba Madre sub basin.

\subsubsection{HBV Model Calibration and Validation Results}

Ten years from period 1993-2002 for calibration which includes one years of warm up period and for the validation from 2003-2006 for validation with one year worm up period from 1992-1993. The model performance of Emba Mader watershed by HBV-96 model are satisfactory with objective functions like Nash-Sutcliffe model efficiency coefficient (NSE) $=0.7$, coefficient of determination $\left(\mathrm{R}^{2}\right)=0.8$, relative volume error $(\mathrm{RVE})=4.8$ and Nash-Sutcliffe model efficiency coefficient (NSE) $=0.88$, coefficient of determination $\left(\mathrm{R}^{2}\right)$ $=0.74$, relative volume error $(\mathrm{RVE})=-4.1$ for the calibration and validation period respectively.

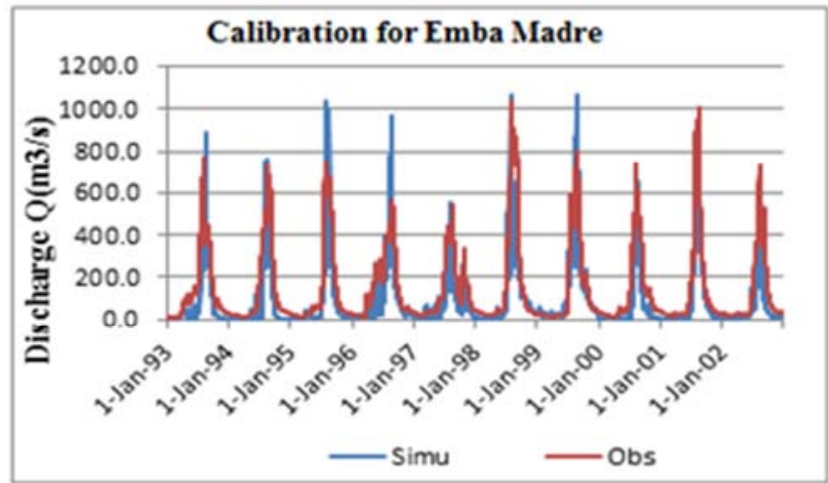

Figure 7. Observed and simulated discharge during calibration period. 


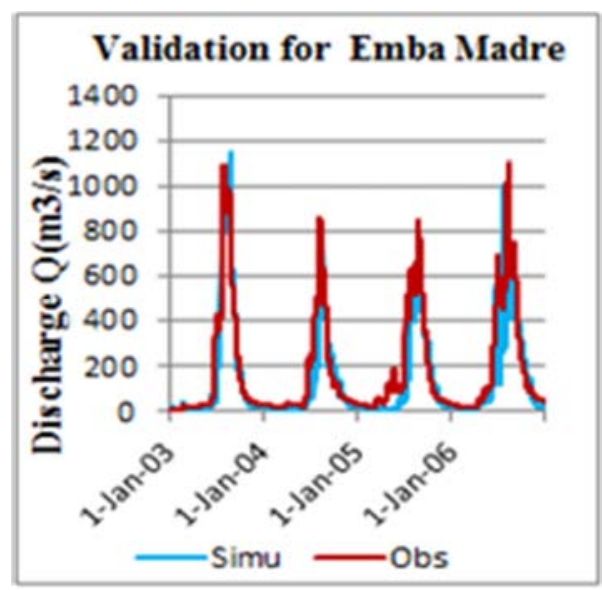

Figure 8. Observed and simulated discharge during validation period.

\subsection{Result of Regionalization}

Checking Model Performance

This research work is not only predicting stream flow at ungauged catchments however, before simulate stream flow at ungauged catchments it is important to check the model performance. For this study take three gauged catchments like Emba Mader, Illala and Gheba let ungauged and transfer model parameters from four gauged catchments like Yechilay, Sulluh, Genfel and Agula using regionalization technique and simulate flow at ungauged catchments. Finally compare simulated and observed flow; if the simulated and observed flows are highly correlated to each other the model has best performance. Following this procedure simulated and observed flow are fitted or best correlated this shows that HBV-96 model has good performance for simulation of steam flow. Especially stream flow computed by multiple linear regression method and observed flow are best correlated to each other; therefore, multiple linear regression method is best compared to others methods. However, other researchers don't check the model performance rather than simulating stream flow for ungauged catchments.

To check the model performance simulated and observed flow comparison of Emba Madre sub catchment was shown in the figure 9 bellow. The results show that the model is reasonably well performed with coefficient of determination $\left(\mathrm{R}^{2}\right)$, Nash-Sutcliffe model efficiency coefficient (NSE) and relative volume error (RVE) are $0.78,0.76$ and 2.6 respectively.

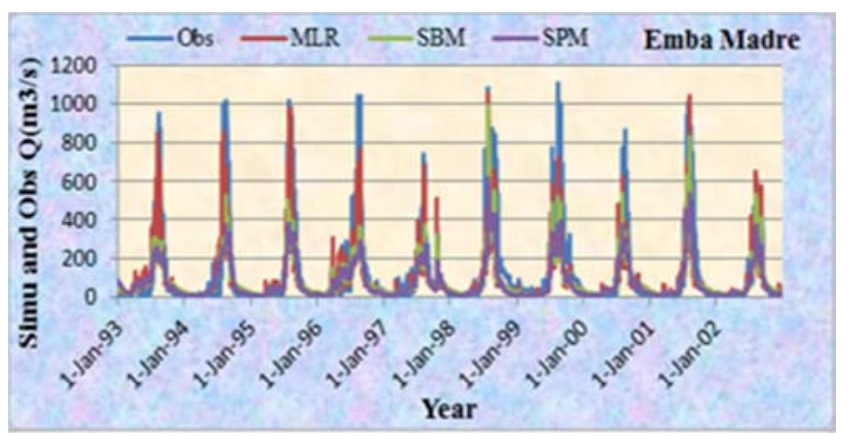

Figure 9. Comparison of observed and simulate flow.

From the above graph simulated flow by multiple linear regression method and observed flow are best correlated to each other; therefore, multiple linear regression method is best comparing to others methods, however in this study multiple linear regression model is the best method it is not contribute high runoff volume however, some researcher's multiple linear regression model contributes high runoff volume compare to other methods. For the next study each regionalization method must be clearly identified and the model performance must be checked.

\subsection{Multiple Linear Regressions Results}

The relationships between physical catchment character tics and model parameters were assessed through multiple linear regression analysis. Depending on the coefficient of determination $\left(R^{2}\right)(\geq 0.85)$ and significance or $p$-value $(\leq$ 0.10 for $95 \%$ confidence interval) physical catchment character tics were selected to establish regression equations.

Table 1. The regional model for model parameters and physical catchment character tics links.

\begin{tabular}{|c|c|c|c|c|c|c|c|}
\hline \multirow{2}{*}{ Coefficients } & \multicolumn{6}{|c|}{$95 \%$ confidence interval } & \multirow{2}{*}{$\begin{array}{l}\text { Co-linearity } \\
\mathbf{R}^{2}\end{array}$} \\
\hline & Model Parametres & Std Error & t-stat & P-value & Lower Bound & Upper Bound & \\
\hline & \multicolumn{6}{|c|}{ Alfa $=B 0+B 1 *$ chromic cambisol $+B 2 *$ barsoil } & \multirow{4}{*}{0.94} \\
\hline BO & 0.5069 & 0.0360 & 14.0651 & 0.0008 & 0.3922 & 0.6216 & \\
\hline$B 1$ & 0.0066 & 0.0010 & 6.6432 & 0.0070 & 0.0034 & 0.0097 & \\
\hline \multirow[t]{2}{*}{ B2 } & -0.0135 & 0.0032 & -4.2060 & 0.0245 & -0.0238 & -0.0033 & \\
\hline & \multicolumn{6}{|c|}{ Beta $=B 0+B 1 *$ Nitosoil $+B 2 * E R$} & \multirow{4}{*}{0.97} \\
\hline BO & 1.8281 & 0.5831 & 3.1355 & 0.0518 & -0.0274 & 3.6837 & \\
\hline$B 1$ & 0.0392 & 0.0060 & 6.5362 & 0.0073 & 0.0201 & 0.0582 & \\
\hline \multirow[t]{2}{*}{$B 2$} & -0.2808 & 0.2599 & -1.0804 & 0.3591 & -1.1079 & 0.5463 & \\
\hline & \multicolumn{6}{|c|}{ Cflux $=\mathrm{B} 0+\mathrm{B} 1 * \mathrm{HI}+\mathrm{B} 2 *$ Mpdry } & \multirow{4}{*}{0.97} \\
\hline BO & 0.9156 & 0.1628 & 5.6244 & 0.0111 & 0.3975 & 1.4337 & \\
\hline$B 1$ & -2.6794 & 0.3604 & -7.4342 & 0.0050 & -3.8264 & -1.5324 & \\
\hline \multirow[t]{2}{*}{$B 2$} & 1.0183 & 0.0930 & 10.9488 & 0.0016 & 0.7223 & 1.3142 & \\
\hline & Ecorr $=\mathrm{B} 0+\mathrm{B} 1 *$ Shur & Land & & & & & \multirow{3}{*}{0.85} \\
\hline B0 & 0.1492 & 0.0145 & 10.2945 & 0.0005 & 0.1090 & 0.1894 & \\
\hline B1 & -0.0014 & 0.0003 & -4.5480 & 0.0104 & -0.0022 & -0.0005 & \\
\hline
\end{tabular}




\begin{tabular}{|c|c|c|c|c|c|c|c|}
\hline \multirow{2}{*}{ Coefficients } & \multicolumn{6}{|c|}{$95 \%$ confidence interval } & \multirow{2}{*}{$\begin{array}{l}\text { Co-linearity } \\
\mathbf{R}^{2}\end{array}$} \\
\hline & Model Parametres & Std Error & t-stat & P-value & Lower Bound & Upper Bound & \\
\hline & \multicolumn{6}{|c|}{$\mathrm{Fc}=\mathrm{B} 0+\mathrm{B} 1 *$ Cambisol+B2*HI } & \multirow{4}{*}{0.82} \\
\hline B0 & 4127.7966 & 1726.3586 & 2.3910 & 0.0751 & -665.3432 & 8920.9365 & \\
\hline B1 & -5.2960 & 8.1468 & -0.6501 & 0.5511 & -27.9152 & 17.3233 & \\
\hline \multirow[t]{2}{*}{$B 2$} & -5010.6934 & 3198.6727 & -1.5665 & 0.1923 & -13891.6326 & 3870.2458 & \\
\hline & \multicolumn{6}{|c|}{$\mathrm{K} 4=\mathrm{B} 0+\mathrm{B} 1 *$ Orthicsolonchaks } & \\
\hline B0 & 0.0087 & 0.0048 & 1.8087 & 0.1303 & -0.0037 & 0.0210 & \multirow{2}{*}{0.91} \\
\hline \multirow[t]{2}{*}{ B1 } & 0.0045 & 0.0006 & 7.0625 & 0.0009 & 0.0029 & 0.0062 & \\
\hline & \multicolumn{6}{|c|}{ Khq $=\mathrm{B} 0+\mathrm{B} 1 *$ chromic cambisol+B $2 *$ Wet Land } & \\
\hline B0 & 0.0050 & 0.0160 & 0.3089 & 0.7776 & -0.0461 & 0.0560 & \multirow[t]{3}{*}{0.9} \\
\hline B1 & 0.0015 & 0.0003 & 5.1184 & 0.0144 & 0.0006 & 0.0025 & \\
\hline \multirow[t]{2}{*}{ B2 } & 0.0007 & 0.0003 & 2.9074 & 0.0621 & -0.0001 & 0.0016 & \\
\hline & \multicolumn{6}{|c|}{ perc $=\mathrm{B} 0+\mathrm{B} 1 *$ Fluvsol $+\mathrm{B} 2 *$ Shurb Land } & \multirow{5}{*}{0.91} \\
\hline B0 & 0.9929 & 0.2803 & 3.5419 & 0.0240 & 0.2146 & 1.7712 & \\
\hline B1 & -0.1183 & 0.0268 & -4.4169 & 0.0115 & -0.1927 & -0.0440 & \\
\hline \multirow[t]{2}{*}{ B2 } & 0.0224 & 0.0050 & 4.4699 & 0.0111 & 0.0085 & 0.0363 & \\
\hline & $\mathrm{lp}=\mathrm{B} 0+\mathrm{B} 1 * \mathrm{PET}$ & & & & & & \\
\hline B0 & 1.6499 & 0.0292 & 56.4151 & 0.0000 & 1.5747 & 1.7251 & \multirow[t]{2}{*}{0.99} \\
\hline B1 & -0.0004 & 0.0000 & -24.1895 & 0.0000 & -0.0005 & -0.0004 & \\
\hline
\end{tabular}

\subsection{Determination of Model Parameters for Ungauged Catchments}

To determine model parameters for ungauged catchments seven flow gauged catchments like Emba Madre, Yechilay, Illala,
Genfel, Sulluh, Agula and Gheba and ten ungauged catchments were selected in upper Tekeze basin. Therefore, to determine model parameters of those ungauged catchments the following four methods were applied or used:

Regional model method: Each model parameters estimated by regional model was derived using equation (Table 1) above.

Table 2. Model parameters estimated for ungauged catchments using regional model.

\begin{tabular}{|c|c|c|c|c|c|c|c|c|c|}
\hline Ungauged catchments & Alfa & beta & Cflux & Ecorr & Fc & k4 & Khq & perc & Lp \\
\hline Uri & 0.505 & 1.64 & -0.03 & 0.149 & 1409.76 & 0.010 & 0.005 & 0.995 & 0.982 \\
\hline Tirare & 0.506 & 1.25 & 0.13 & 0.148 & 818.71 & 0.009 & 0.005 & 1.009 & 1.019 \\
\hline U/s Tirare & 0.507 & 1.28 & 0.22 & 0.149 & 976.54 & 0.009 & 0.005 & 1.004 & 1.027 \\
\hline U/s Lalibela & 0.506 & 1.41 & 0.04 & 0.149 & 812.77 & 0.009 & 0.005 & 1.004 & 1.004 \\
\hline Nr. Angereb & 0.506 & 1.30 & 0.08 & 0.149 & 1516.08 & 0.010 & 0.005 & 0.993 & 0.977 \\
\hline U/s Angereb & 0.506 & 1.07 & 0.08 & 0.149 & 895.49 & 0.009 & 0.005 & 0.968 & 1.004 \\
\hline U/s Yechilay & 0.505 & 1.13 & 0.07 & 0.148 & 1502.91 & 0.009 & 0.005 & 1.005 & 1.009 \\
\hline Gobay & 0.506 & 1.20 & 0.32 & 0.148 & 1084.40 & 0.009 & 0.005 & 1.002 & 1.002 \\
\hline Mean & 0.506 & 1.294 & 0.22 & 0.148 & 1143.99 & 0.009 & 0.005 & 0.996 & 0.960 \\
\hline
\end{tabular}

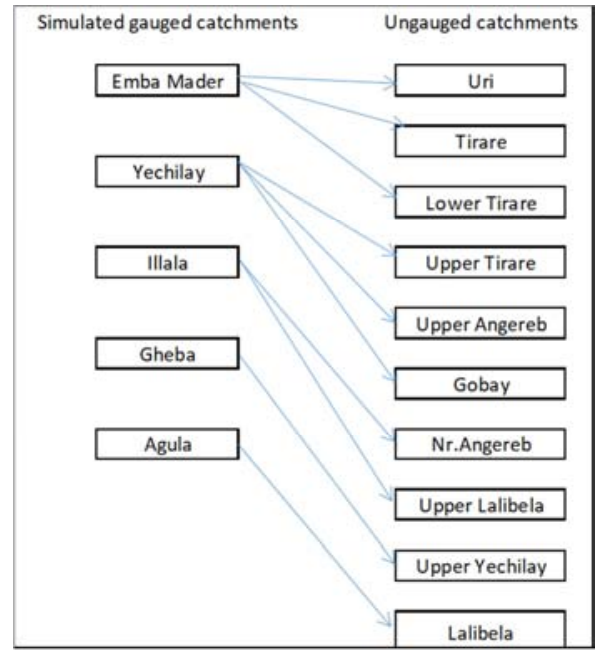

Figure 10. Model parameters transfer by spatial proximity method.

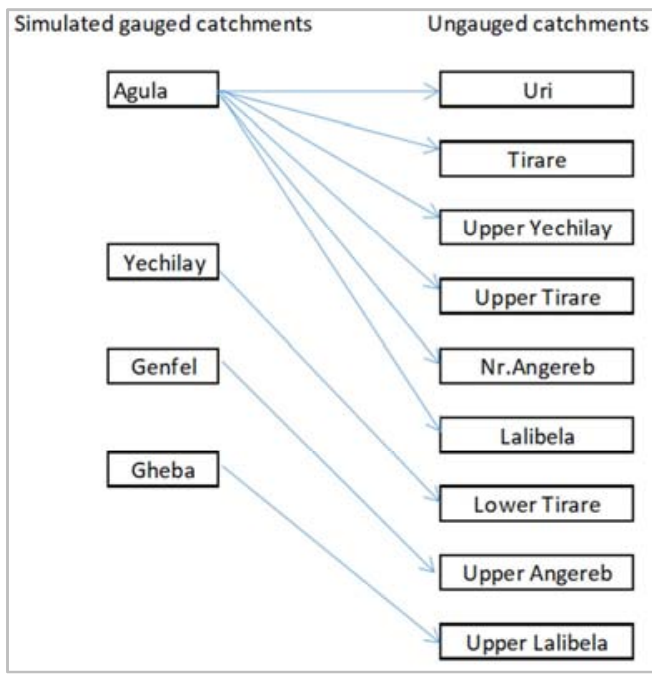

Figure 11. Model parameters transfer by area ratio method. 
Spatial proximity method: Transferring model parameters from gauged catchments to ungauged catchments based on similarity of catchment characteristics (Figure 10) using spatial proximity Method. Similarity of catchment characteristics between gauged and ungauged catchments of upper Tekeze sub-basins are as shown below.

Area ratio method: In case of area ration method Emba Madre model parameters is not transferring any ungauged catchments because area ratio between Emba Madre and those ungauged catchments are greater than 50\%. Figure 11 . shows that model parameters transferred from gauged to ungauged catchments based on area ratio method.

\section{Sub-basin mean method}

The average value of gauged catchments (Emba Madre, Yechilay, Illala, Genfel, Agula and Gheba) model parameters were taken for each ungauged catchment to simulate stream flow for ungauged catchments based on the principle of subbasin mean method.

\subsection{Simulation of Stream Flow at Ungauged Catchments}

Model parameters estimated from ungauged catchments were simulated by HBV-96 model. Monthly average simulated flow for ungauged upper Tirare sub-catchments shown in the following Figure 12 in four methods i.e., Multiple Linear Regression (MLR), Sub basin mean (SBM), Spatial Proximity (SPM) and area ratio (AR) method.

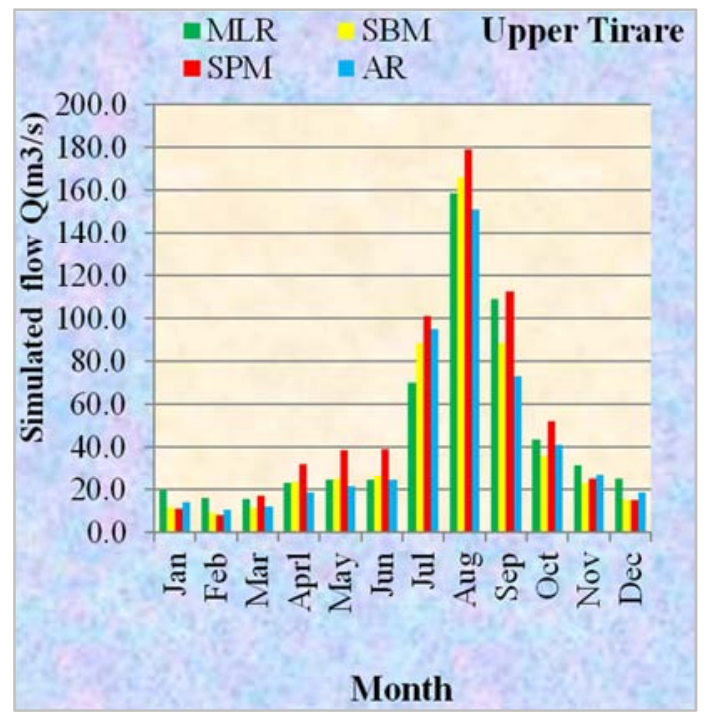

Figure 12. Monthly average simulated flow for selected sub catchments.

The above figure show that runoff simulated by spatial proximity and sub basin mean method contributes high runoff volume compare to other two methods. This implies that area ration method is poor because it is only considering the size between gauged and ungauged catchment areas. However, runoff estimated by multiple linear regressions are best fitted with observed flow, therefore this method is appropriate to predict discharge for ungauged catchments compare to other methods in upper Tekeze sub basins.

In this study multiple linear regression model is the best method it is not contribute high runoff volume however, some researcher's analyze multiple linear regression model contributes high runoff volume compare to others methods. For next study each regionalization method must be clearly identified using syntiffic approach.

\section{Conclusions}

Based on the applied methodology and results obtained, the following conclusions are drawn:

In upper Tekeze sub-basin there are some gauging stations while seven of them have continuous river flow data from 1992 to 2006 . Those have been simulated with a reasonable performance Nash-Sutcliffe model efficiency coefficient (NSE) greater than 0.60 and relative volume error (RVE) smaller than $+10 \%$ or $-10 \%$.

Before simulating stream flow for ungauged catchments three best flow record gauged catchments lets assumed ungauged. Transfer model parameters from gauged to ungauged catchments and then simulate stream flow for those ungauged catchments. Finally compare simulated and observed flow by different methods in order to checking the model performance. For this study the model is well performed.

The model was calibrated and validated at gauged catchments from 1993 to 2002 and 2003 to 2006 respectively. Sensitivity analysis of HBV-96 model parameters was carried out manually by trial-and-error procedure.

According to sensitivity analysis, runoff coefficient (Beta), recession coefficient of upper reservoir zone (Khq), percolation (Perc), Limit for evapotranspiration (Lp), and field capacity $(\mathrm{Fc})$ were more sensitive model parameters while recession coefficient for lower reservoir $\left(\mathrm{K}_{4}\right)$, capillary rise coefficient (cflux) and parameters response routine (alfa), are relatively less sensitive for upper Tekeze sub-basin.

Model parameters for ungauged catchments are estimated by regional model, spatial proximity, catchment area ratio and sub-basin mean method. The model parameters of Emba Madre catchments were not transferred to any ungauged catchments since the area ratio between Emba Madre and ungauged catchments were greater than $50 \%$.

For this study comparisons of regionalization methods indicate that stream flow simulation at ungauged catchments estimation by spatial proximity, sub basin mean and area ration method contributes high and less runoff volume respectively. Therefor for upper Tekeze sub-basin multiple linear regression method is best compare to other methods. Generally, in upper Tekeze river basin HBV-96 model is found to be acceptable results for estimation daily stream flow at ungauged catchments.

\section{Recommendations}

The following recommendations are given on the basis of the next research work on upper Tekeze sub-basins:

In this study it is observed that parameters response routine (alfa), capillary rise coefficient (cflux) and recession coefficient for lower reservoir $\left(\mathrm{K}_{4}\right)$ do not show significant 
effect on the model performance. Thus, it can be kept as default value when applying $\mathrm{HBV}$ model to the next regionalization studies.

In this study multiple linear regression model is the best method consequently not contribute high runoff volume however, some researcher's analyze multiple linear regression model contributes high runoff volume compare to others methods. For next study each regionalization method must be clearly identified.

HBV-96 model calibrated manually by try and error procedure as keeping the other model parameters are constant and one model parameter is changing within the range, so for this study more advanced automatic model calibration techniques could be useful for the next time.

Further recommendation for the concerned body Tekeze river basin is one of the $12^{\text {th }}$ river basins in Ethiopian and contributes in hydropower, water supply and irrigation however, most part of sub basins flow gauged catchments are missing or no recorded flow data and no more research's work were done in the previous time, therefore the concerned

body must be follow-up monitoring service for river flow gauged catchments and further research work are motivated in the basin in order to use water resources effectively.

\section{References}

[1] Aghakouchak, A., Nakhjiri, N., and Pradhan, N. R.. (2012). An educational model for ensemble stream flow simulation and uncertainty analysis. Journal of Hydrology and Earth System Science Discussion.

[2] Akawka, A. L.; Haile, Alemseged Tamiru.(2014). Regionalization of conceptual rainfall-runoff model parameters for predicting stream flows of ungauged catchments in the Blue Nile Basin In Eastern Nile Technical Regional Office (ENTRO). Second New Nile Conference on New Nile Opportunities: Scientific Advances towards Prosperity in the eastern Nile Basin, Addis Ababa, Ethiopia, 89 December 2014. Book of abstracts, Addis Ababa, Ethiopia: Eastern Nile Technical Regional Office (ENTRO). pp. 96.

[3] Bates, B. C. (1994) Regionalization of hydrologic data: a review. Cooperative Research Centre for Catchment Hydrology, Monash University, Victoria, Australia.

[4] Birhane, M. (2013). Estimation of monthly flow for ungauged catchment (Case Study Baro - Akobo basin) Ethiopia. MSc thesis. Addis Ababa University, Ethiopia.

[5] Bishaw, Y. (2012). Evaluation of climate change impact on Omo Gibe basin (case study of Gilgel Gibe III reservior), Ethiopia MSc thesis. Addis Ababa Univesity, Ethiopia.

[6] Hundecha. ( 2005). regionalization Parameters of Conceptual Rainfall - Runoff Model,. University of Stuttgart Germany.

[7] Kim, U. and Kaluarachchi, J. J., "Application of parameter estimation and regionalization methodologies to ungauged basins of the Upper Blue Nile River Basin, Ethiopia" (2008). ungauged catchments; Case study in Zimbabwe. ITC, Enshede.

[9] Merz, R. and Blaschl, G. (2004).. Regionalization of catchment model parameters. Journal of Hydrology, 287 (1-4): 95-123.

[10] Moreda, F. (1999). Conceptual Rainfall-Runoff Models for Different Time Steps with Special Consideration for Semi-arid and Arid Catchments Laboratory of Hydrology and InterUniversity Program in Water Resources Engineering Vrije Universiteit Brussel.

[11] Oyebande, L. (2001), Streamflow regime change and ecological response in the Lake Chad Basin in 27 Nigeria., in: Hydro-ecology: Linking Hydrology to Aquatic Ecology, IAHS Publ. No. 266. Ed. 28 Mike Acreman, International Association of Hydrological Sciences, p. 101-111.

[12] Prajakta, J. and Bloschl, G (2005). A comparison of regionalization methods for catchment mod Hydrological Earth System rological Earth System Science, 9: 157-171.

[13] Perera, U. (2009). Ungauged catchment hydrology. Case study on Lake Tana Basin, Ethiopia. Enshede, Netherlands.

[14] Seibert, J. (1999). Conceptual runoff models fiction or representation of reality? Acta Univ. Ups., Comprehensive Summaries of Uppsala Dissertations from the Faculty of Science and Technology 436. 52 pp. Uppsala. ISBN 91-5544402-4, Uppsala University, Swed.

[15] Tufa, K. (2011). Performance comparison of conceptual rainfall-runoff models on Muger catchment (Abbay River Basin). MSc Thesis. Addis Ababa University, Ethiopia.

[16] Vandewiele, G and Elias, A. (1995). Monthly water balance of ungauged catchments obtained by geographical reginalization. Journal of Hydrology, 170 (1-4): 277-291.

[17] White K. L. and Chaubey I., (2005). Sensitivity Analysis, Calibration and Validations for a Multisite and Multivariable SWAT Model. Journal of the American Water Resources Association (JAWRA), 41 (5): 1077-1089.

[18] Xiangyi Kong, Zhijia Li, Zhiyu Liu, "Flood Prediction in Ungauged Basins by Physical-Based TOPKAPI Model", Advances in Meteorology, vol. 2019, Article ID 4795853, 16 pages, 2019.

\section{Biography}

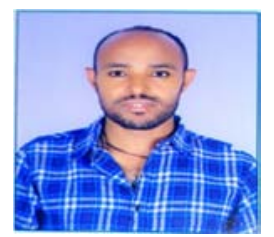

I am Amare Tadesse Muche, when I was completed grade 12th, I joined Hawassa University in department of Water Resources and Irrigation Engineering after finishing 5 years study I acquired Bachelor degree in water Resources and Irrigation Engineering. Arba Minch university employed me as Assistance lecturer at 2014 G.C and in 2017 G.C. I hold my MSc. degree in Hydraulic and Water Resources Engineering and still I am working at Arbaminch Water Technology Institute as senior Lecturer and I also done so many research papers in our Institute and collaborative research engagement for the community as well as the Institute itself.

[8] Mazvimavi, D. (2003). Estimation of flow characteristics of 